\title{
Seizing moments
}

Lala Tanmoy Das, MS

Neurology ${ }^{\circledR}$ 2018;90:933. doi:10.1212/WNL.0000000000005520

We were playing hide-and-seek underneath a leafy frock of almond trees when suddenly

my sister froze, robbed of motion temporarily until, beneath a scarf of autumn breeze,

she fell onto a strip of road, paved in stone, her bony arms arched upwards,

while restless quivers turned into fired shots of squeeze, squeeze, squeeze, clenched fists, rocky

lips, eyes behind the cup of lids, muscles below her wrap of skin, tightening spasmodically.

Her C-shaped spine rocked back and forth, while shock-like jerks gripped furiously

her crowded map of nerves. Balls of froth spewed soundless screams, in between

convulsions. I yelled for help

but there was not a soul nearby, not a bird in the sky,

the first responders far away. Moments passed by as I watched her body squirm and writhe, tense

up, contort into a cold apostrophe, breaths

growing thick over purple lips - until about a minute passed

the spasms died, the clench subsided, the slur of words resolved, her vacant eyes filled up with light,

and she jolted awake in disbelief. This was many years ago, when she was 12 and I was 4; yet, it remains

so vivid in my mind: that cloudless sky, Nature's course, an empty road, and her body's overshot circuitry.

\section{Correspondence}

Mr. Das

lad2027@med.cornell.edu

\section{MORE ONLINE}

ค Audio

Listen to Mr. Das read this poem.

NPub.org/q6hndl 


\title{
Neurology
}

\author{
Seizing moments \\ Lala Tanmoy Das \\ Neurology 2018;90;933 \\ DOI 10.1212/WNL.0000000000005520
}

\section{This information is current as of May 14, 2018}

\section{Updated Information \&} Services

\section{Subspecialty Collections}

Permissions \& Licensing

\section{Reprints}

including high resolution figures, can be found at: http://n.neurology.org/content/90/20/933.full

This article, along with others on similar topics, appears in the following collection(s):

All Epilepsy/Seizures

http://n.neurology.org/cgi/collection/all_epilepsy_seizures

EEG; see Epilepsy/Seizures

http://n.neurology.org/cgi/collection/eeg_see_epilepsy-seizures

Information about reproducing this article in parts (figures,tables) or in its entirety can be found online at:

http://www.neurology.org/about/about_the_journal\#permissions

Information about ordering reprints can be found online:

http://n.neurology.org/subscribers/advertise

Neurology ${ }^{\circledR}$ is the official journal of the American Academy of Neurology. Published continuously since 1951, it is now a weekly with 48 issues per year. Copyright (O 2018 American Academy of Neurology. All rights reserved. Print ISSN: 0028-3878. Online ISSN: 1526-632X.

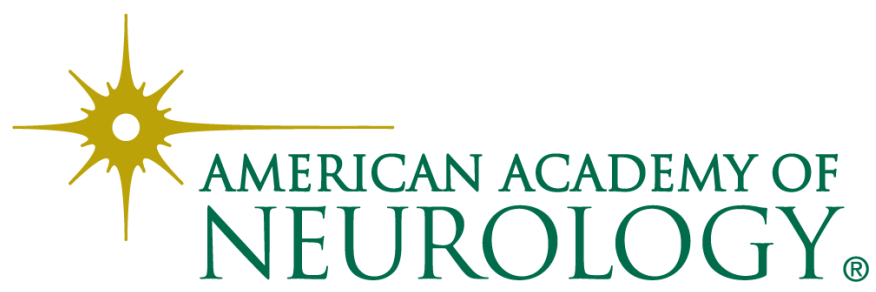

